\title{
UPAYA MENINGKATKAN HASIL BELAJAR MATEMATIKA MENGGUNAKAN MODEL PEMBELAJARAN THINK PAIR SHARE BERBANTUKAN MEDIA VISUAL PADA PESERTA DIDIK KELAS III SDN 3 PALANGKA TAHUN PELAJARAN 2016/2017
}

\author{
Oleh : Rizki Amalia*Karyanti, M.Pd*
}

\begin{abstract}
Abstrak
Penelitian ini bertujuan untuk: (1) Mengetahui aktivitas belajar Matematika peserta didik kelas III SDN 3 Palangka Palangka Raya dengan menggunakan model pembelajaran kooperatif Think Pair Share Berbantukan Media Visual. (2) Mengetahui ada atau tidaknya peningkatkan hasil belajar Matematika peserta didik kelas III SDN 3 Palangka Palangka Raya dengan menggunakan model pembelajaran Think Pair Share Berbantukan Media Visual. Metode penelitian yang digunakan adalah Penelitian Tindakan Kelas (PTK) yang berusaha memecahkan atau menjawab permasalahan dalam pembelajaran.Subjek dalam penelitian ini adalah seluruh peserta didik kelas III SDN 3 Palangka Palangka Raya yang berjumlah 20 peserta didik yang terbagi dalam 9 laki-laki dan 11 perempuan.Teknik pengumpulan data yang digunakan adalah observasi dan tes. Teknik analisis data dalam penelitian ini adalah kualitatif dan kuantitatif. Hasil penelitian ini menunjukan bahwa: (1) Aktivitas belajar peserta didik kelas III SDN 3 Palangka Palangka Raya dengan menggunakan model pembelajaran Kooperatif Think Pair Share Berbantukan Media Visuallebih aktif dengan kriteria bagus. (2) Terdapat peningkatan hasil belajar Matematika dengan menggunakan model pembelajaran kooperatif Think Pair Share pada peserta didik kelas III SDN 3 Palangka Palangka Raya. Hasil belajar data awal mencapai nilai rata-rata 58 dengan ketuntasan data klasikal $25 \%$ dan mengalami peningkatan pada siklus I nilai rata-rata 90 dengan presentase ketuntasan data klasikal $100 \%$.
\end{abstract}

KATA KUNCI: Hasil Belajar, Model Kooperatif Think Pair Share, Media Visual.

\section{PENDAHULUAN}

Pendidikan adalah proses pengubahan sikap dan perilaku seseorang atau kelompok orang dalam usaha mendewasakan manusia melalui upaya pengajaran dan penelitian. Dalam bukubuku tentang pendidikan seringkali pengertian pendidikan di definisikan orang berbeda-beda, menurut SA Branata dkk dalam Sofan Amri (2013: 5) pendidikan adalah usaha yang sengaja diadakan, baik secara langsung maupun tidak langsung untuk membantu anak dalam perkembangannya mencapai kedewasaan.

Pendidikan yang berkualitas tidak terlepas dari proses pembelajaran, pembelajaran merupakan komunikasi dua arah, mengajar dilakukan oleh pihak pendidik yaitu guru, sedangkan belajar dilakukan oleh peserta didik. Dalam proses pembelajaran guru dituntut mampu menciptakan situasi pembelajaran yang aktif, inovatif, kreatif, dan menyenangkan (PAKEM). Agar proses pembelajaran menjadi lebih efektif, peserta didik seharusnya difahami lebih dari sekedar penerima pasif pengetahuan, melainkan dalam proses pembelajaran peserta didik harus ikut berperan aktif. Khususnya dalam pembelajaran matematika, matematika biasanya di anggap pelajaran yang sulit oleh anak-anak maupun orang dewasa. Pembelajaran matematika adalah suatu proses pembelajaran yang dibangun 
guru untuk mengembangkan dan meningkatkan kemampuan berfikir peserta didik, serta dapat meningkatkan kemampuan mengkonstruksi pengetahuan baru sebagai upaya meningkatkan penguasaan yang baik terhadap pelajaran matematika. Menurut muijs \& Reynolds (2008: 332) pada sejumlah studi yang dilaksanakan oleh the basic skill agency cukup banyak orang dewasa yang tidak memiliki keterampilan numerasi dasar.Mengingat pentingnya matematika dan masalah yang dimiliki banyak orang dengan subjek ini, maka tidak mengeherankan bila ada cukup banyak penelitian tentang kemampuan murid untuk berfikir dan belajar matematika.

Disekolah banyak ditemukan saat mengajar dan penyampaian materi guru hanya menggunakan metode ceramah dan contoh-contoh soal yang jarang melibatkan peserta didik secara langsung dalam penyampaian dan penjelasan materi, hingga banyak peserta didik yang kesulitan dalam belajar matematika bahkan ada peserta didik yang tidak menyukai pelajaran matematika karena selalu mendapat nilai rendah disebabkan kesulitannya memahami materi pelajaran dan guru yang kurang melibatkan peserta didik secara langsung pada saat proses pembelajaran berlangsung. Hal ini dikarenakan jarangnya penggunaan model dan media pembelajaran yang bervariasi yang dapat digunakan dalam pelaksanaan pembelajaran matematika, serta kurangnya pemanfaatan keaktifan peserta didik dalam pembelajaran.Baiknya guru dalam melaksanakan pembelajaran mengkombinasikan pembelajaran dengan penggunaan model pembelajaran dan penggunaan media embelajaran kemudian melibatkan peserta didik dalam penjelasan dan penyampaian materi. Salah satu model pembelajaran dan media pembelajaran yang dapat digunakan guru dalam pembelajaran matematika adalah model pembelajaran kooperatif Think Pair Share dan media visual.

Berdasarkan hasil observasi di SDN -3 Palangka Palangkaraya yang dilaksanakan peneliti pada tanggal 15 hingga tanggal 25 November 2016, pada proses pembelajaran matematika terlihat adanya kesulitan pemahaman dan kebingungan peserta didik pada rumusrumus matematika keliling persegi dan persegi panjang dan hasil belajar peserta didik banyak yang tidak tuntas, hal ini diidentifikasikan dari hasil belajar peserta didik yang belum memenuhi Kriteria Ketuntasan Minimum (KKM) yaitu 70. Di ketahui bahwa dalam proses pembelajaran Matematika pada kelas III nilai yang diperoleh peserta didik masih ada yang di bawah nilai 70. Dimana dari jumlah peserta didik 20 orang ada sekitar 14 orang (70\%) peserta didik mendapat nilai di bawah Kriteria Ketuntasan Minimal (KKM) dan ada sekitar 6 orang (30\%) peserta didik yang mencapai Kriteria Ketuntasan Minimal (KKM). Berikut data nilai peserta didik kelas III dalam mata pelajaran Matematika.

Dari fenomena diatas dapat disimpulkan bahwa rendahnya hasil belajar Matematika peserta didik disebabkan karena kurangnya variasi dalam proses pembelajaran yang dilaksanakan, hal ini karena guru kurang mengikut sertakan peserta didik dalam proses pembelajaran, pembelajaran terkesan hanya satu arah tidak ada timbal balik, sehingga menimbulkan kesulitan peserta didik dalam belajar dan memahami materi yang diberikan yang kemudian 
berpengaruh terhadap hasil belajar peserta didik. Untuk mengatasi hal tersebut salah satu model pembelajaran yang dapat digunakan yaitu dengan menerapkan model pembelajaran kooperatifThink Pair Share dan media visual.

\section{METODE PENELITIAN}

Penelitian ini merupakan Penelitian Tindakan Kelas (PTK). Pengertian Penelitian Tindakan Kelas menurut Hopkins dalam Kunanadar (2013: 46) menyatakan bahawa PTK adalah penelitian untuk membantu seseorang dalam mengatasi secara praktis persoalan yang dihadapi dalam situasi darurat dan membantu pencapaian tujuan ilmu sosial dengan kerja sama dalam kerangka etika yang disepakati bersama. Suatu penelitian akan menghasilkan kesimpulan yang tepat, apabila menggunakan jenis penelitian yang tepat dan benar sesuai dengan masalah yang diteliti, situasi, dan kondisi saat penelitian tersebut dilakukan.

Berdasarkan jenis penelitian yang digunakan yaitu penelitian tindakan kelas (PTK), maka peneliti hadir selama penelitian disekolah berlangsung.Peran peneliti adalah melakukan penelitian dan metodeMixed Methods atau metode kombinasi antara kualitatif dan kuantitatif. Miftahul Huda, 2013) menjelaskan mixed methods atau metode campuran adalah "pedoman pada arah dari kumpulan analisis data dan gabungan dari penelitian kualitatif dan kuantitatif dalam banyak fase pada proses penelitian"..

1) Pengamatan aktivitas guru dan peserta didik

2) Hasil belajar IPA peserta didik menggunakan Model Pembelajaran Think Pair Share berbantukan media visua berklaborasi dengan guru kelas III dan dibantu oleh teman sejawat sebagai observer agar penelitian dapat berjalan dengan lancar dan mencapai tujuan pembelajaran yang diharapkan.Di samping itu, peneliti juga mengumpulkan dan menganalisis data serta sebagai pelapor hasil penelitian.

Dalam pelaksanaan penelitian tindakan kelas ini yang menjadi subjek penelitianadalah peserta didik kelas V semester genap yang berjumlah 18 orang.Terdiri dari 8 peserta didik perempuan dan 10 peserta didik lakilaki.Sedangkan yang menjadi objek penelitian adalah hasil belajar IPA.

Pengumpulan data yang diperoleh pada penelitian ini dilakukan melalui pengamatan (observasi) dan tes hasil belajar.

Data yang dikumpulkan dari setiap siklus akan di analisis menggunakan. Data kuantitatif berasal dari hasil tes yang diberikan pada setiap akhir siklus kegiatan. Hal ini dilakukan untuk mengetahui peningkatan hasil belajar peserta didik pada pendekatan yang diterapkan

\section{HASIL DAN PEMBAHASAN}

Data dari hasil penelitian ini berupa : 1) pengamatan aktivitas guru dan peserta didik 2) hasil belajar Matematika menggunakan model pembelajaran Think Pair Share berbantukan media visual

Aktivitas guru dan peserta didik dapat dilihat pada tabel dan gambar berikut 
Berdasarkan tabel hasil post test pada siklus I terlihat hasil belajar peserta didik kelas III SDN 3 Palangka Palangkaraya dengan rata-rata 90 dengan ketuntasan klasikal mencapai $100 \%$ ini berarti pada siklus ke I ketuntasan belajar individu sudah mencapai dan dianggap tuntas, jadi tidak perlu ada tindakan selanjutnya Adapun peningkatan hasil belajar dapat dilihat dalam gambar diagram berikut : untuk memperbaiki hasil belajar kelas III SDN 3 Palangka Palangkaraya karena target dalam penelitian ini adalah standar KKM 70 sudah tercapai, dan tingkat ketercapaian ketuntasan hasil belajar peserta didik secara klasikalnya sudah melebihi target yang diinginkan, yaitu $85 \%$.

\section{Gambar 5}

Diagram Hasil Rekapitulasi Nilai Rata-Rata dan Ketuntasan Hasil Belajar Matematika Peserta Didik Kelas III SDN 3 Palangka

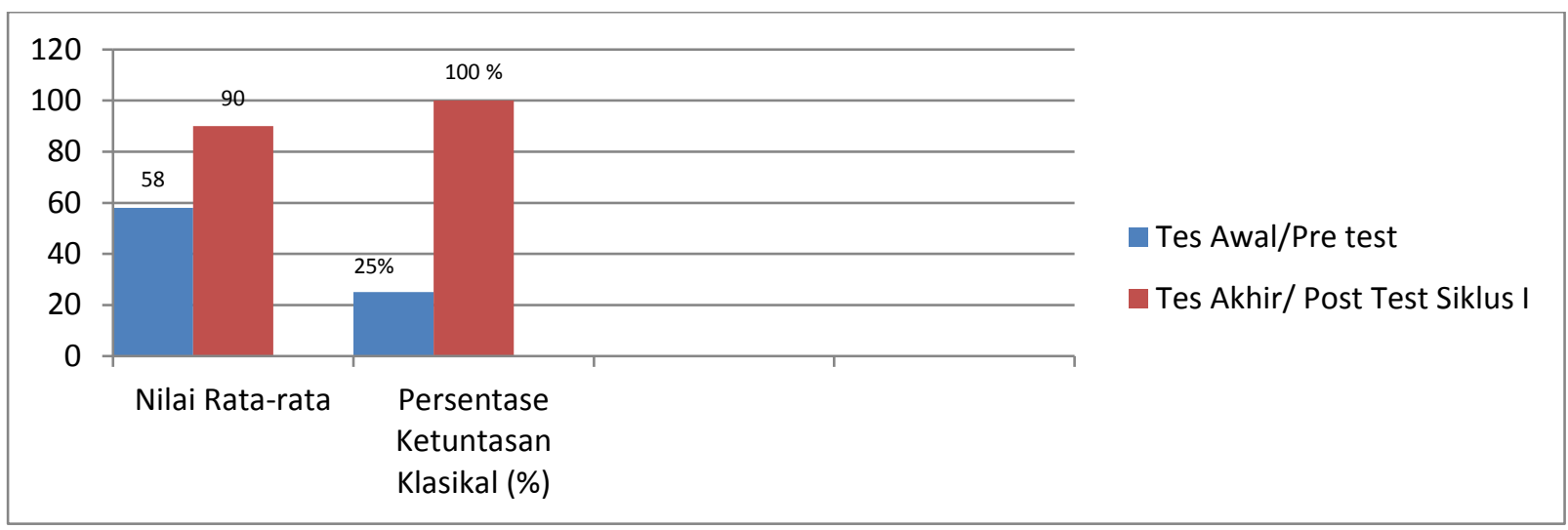

\section{SIMPULAN}

Berdasarkan data dari hasil penelitian dan pembahasan dalam penelitian tindakan kelas (PTK) pada siklus I di kelas III SDN -3 Palangka, maka dapat diambil kesimpulan sebagai berikut:

1. Aktivitas belajar pada saat pembelajaran Matematika dengan menggunakan model pembelajaran kooperatif Think Pair Share berbantukan media visual pada peserta didik kelas III SDN -3 Palangka Palangka Raya Tahun Pelajaran 2016/2017 menjadi lebih baik, karena peserta didik aktif dan antusias mendengarkan penjelasan guru serta bersemangat dalam mengikuti proses pembelajaran. Hal ini dapatdilihat dari hasil pengamatan yang dilakukan oleh dua orang pengamat yang mendapatkan skor rata-rata 3,8 dengan kriteria sangat baik.

2. Ada peningkatan hasil belajar Matematika dengan menerapkan model Think Pair Share berbantukan media Visua pada peserta didik kelas III SDN -3 Palangka Tahun Pelajaran 2016/2017. Dapat dilihat dari hasil pre test yang mendapatkan nilai rata-rata 58 dan ketuntasan secara klasikalnya hanya $25 \%$, kemudian pada siklus I setelah diberikan tindakan nilai rata-rata peserta didik meningkat menjadi 90 dan ketuntasan secara klasikalnya yaitu $100 \%$, dari ketetapan yang sudah ditentukan yaitu Kriteria Ketuntasan Minimum sebesar 70 dan kriteria ketuntasan secara klasikal sebesar $85 \%$. 
Tunas Jurnal Pendidikan Guru Sekolah Dasar,Desember 2017, Volume 3 Nomor 1, (21-26) ISSN 2477-6076

Dengan ini maka dapat di simpulkan bahwa ada peningkatan hasil belajar Matematika setelah diterapkannya model pembelajaran kooperatif Think Pair Share berbantukan media Visual.

\section{DAFTAR PUSTAKA}

Huda, Miftahul. 2013. Model Model Pegajaran dan Pembelajaran. Pustaka Belajar: Yoyakarta 
Tunas Jurnal Pendidikan Guru Sekolah Dasar,Desember 2017, Volume 3 Nomor 1, (21-26) ISSN 2477-6076 